\title{
The keratin intermediate filament-like system in maize protoplasts
}

Su Fei, Gu Wei and Zhai Zhonghe

Department of Biology, Bejing University, Beijing 100871, China

\begin{abstract}
The application of Penman's method of cell fractionation to plant protoplasts leads to our finding of keratin intermediate filament(IF)-like system in maize protoplasts, which was identified by using immunogold labelling with monoclonal antibody of cytokeratin from animal cells. Many gold particles were found to be bound on filaments, linked by $3 \mathrm{~nm}$ filaments. After further digestion and extraction with DNase I and ammonium sulphate, IF-like framework-lamina-nuclear matrix system was shown under electron microscope. That IF system exists in plant protoplasts just like in animal cells, and their main component is keratin-like protein.
\end{abstract}

Key words: keratin intermediate filament-like system, keratin-like protein, maize protoplasts.

\section{INTRODUCTION}

Since Ishikawa et al. (1968) found $10 \mathrm{~nm}$ filaments in animal cells, and termed it as "intermediate size filaments"[1,2], many scientists have focused their attention on the morphology and function of this intermediate filament[3,4] (IF). In most of the past works, IFs were found to be densely distributed around cell nuclei using immunofluorescence, so that IFs were thought to act as support framework for the anchorage of the nucleus. S. Penman et al. had developed a procedure for cell fractionation and got a complex of nuclear matrix and IFs called NM-If scaffold. Under electron microscopy, by using this method, an IFs-lamina-nuclear matrix system could be shown in animal cells e.g. HeLa cells[5-9].

But for the past twenty years, no one has demonstrated that IFs are existed in plant cells using electron microscopy directly. In 1985, Dawson et al. showed that anti-IF reacted with polypeptides present in a high salt Triton X-100 insoluble fraction in higher plant Allium cepa[10]. Miller et al. demonstrated the similar result 
Keratin intermediate filament-like system in maize protoplaste

existed in algae Chlamydomonas[11]. It indicated that some evolutionary conservative proteins, just like the proteins of IFs in animal cells i.e. keratin, vimentin, existed in some plant cells. However it needs much more evidence to prove IFs in plant cells. Besides all these, so far no one ever either studied morphological characteristics or even completely identified that $10 \mathrm{~nm}$ filaments in plant cells.

Here we applied the method for cell fractionation to show IFs in maize protoplasts. At the same time, we succeeded in identifying IFs using immunogold labelling with monoclonal antibody of cytokeratin which has not been reported so far.

\section{MATERIAL AND METHODS}

\section{Plant materials and protoplast isolation:}

Maize (Zea may L.) was grown in soil in a greenhouse within a day-night temperature range of $25^{\circ} \mathrm{C}$ to $12^{\circ} \mathrm{C}$. Leaf tissue was taken four weeks after planting. Six to nine leaves at a time were sampled, stacked, and cut by hand into small segments about $0.7 \mathrm{~mm}$ in width and then subjected to enzyme medium which contained $0.5 \mathrm{M}$ sorbitol, $1 \mathrm{mM} \mathrm{CaCl} \mathrm{Cl}_{2}, 0.1 \% \mathrm{BSA}, 2 \%$ cellulase (Onozuka R-10), and $0.3 \%$ pectinase (Sigma, pH 5.0) by incubating in a conical flask on a shaker $(30 \mathrm{rpm})$ at $20^{\circ} \mathrm{C}$.After 10-20 hours, digestion mixture was filtered using a 37 $\mu \mathrm{m}$ nylon mesh. The filtered protoplast, being free from wall remnants as judged by cal-cofluor staining[13], was washed five times by centrifugation $(300 \times \mathrm{g}$ for $3 \mathrm{~min}$.) in the isolation

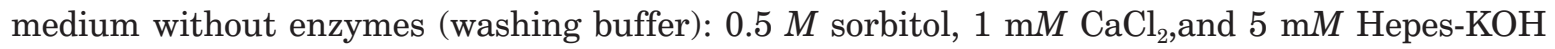
$(\mathrm{pH} 7.0)$

\section{Protoplast fractionation:}

Washed protoplasts were attached to formvar/carbon-coated grids with poly-L-lysine. After $20 \mathrm{~min}$, unattached protoplasts were then washed off by two rinses in washing buffer used in protoplast preparation. Protoplast extraction was essentially as descrided by Fey et al.[5] with some modification by Zhai et al.[7,8,9]. All steps were made at $4^{\circ} \mathrm{C}$.Protoplasts were extracted in cytoskeletal (CSK) buffer (10 mM PIPES, $100 \mathrm{~m} M \mathrm{KCl}, 300 \mathrm{~m} M$ sucrose, $3 \mathrm{~m} M$ $\mathrm{MgCl}_{2}$, $1 \mathrm{~m} M$ EGTA, $1.2 \mathrm{~m} M$ phenylmethylsulfonyl fluoride, and $0.5 \%$ (v/v) Triton X-100, pH6.8) for 2-3 min, then extracted in RSB-Magik (42.5 mM Tris, $8.5 \mathrm{~m} M$ NaCl, $2.6 \mathrm{mM} \mathrm{MgCl}_{2}$ $1.2 \mathrm{mMphenylmethylsulfonyifluoride,} 1 \%$ (v/v) Tween 40, and $0.5 \%(\mathrm{v} / \mathrm{v})$ sodium desoxycholate $\mathrm{pH}$ 8.3) for 5 minutes. DNase I digestion (200 $\mu \mathrm{g} / \mathrm{ml}$ DNase I) proceeded for 20 minutes at room temperature before ammonium sulfate was added to a final concentration of $0.25 M$ in digestion buffer(the same as CSK buffer except with $50 \mathrm{mM} \mathrm{NaCl}$ instead of $\mathrm{KCl}$ ) and incubated further for 3-5 minutes. This step removes the chromatin fraction and leaves the nuclear matrix IFs structure intact.

\section{Immunogold labelling for electron microscope:}

After extraction, protoplasts were fixed with 0.1-0.2\% glutaraldehyde for 1-2 minutes, rinsed with $\mathrm{NaBH}_{4}(0.5 \mathrm{mg} / \mathrm{ml})$ in PBS for 5 minutes to wash out excess glutaraldehyde 
incubated withmonoclonal antibody of cytokeratin (Kindly given by Dr. Sun T.T., professor of New York University Medical Center) at $37^{\circ} \mathrm{C}$ for 30 minutes, and then incubated with colloidal gold-protein A (Sigma) for 20 minutes. After this, the grids were washed five times for a total of 25 minutes in CSK and 1\% bovine serum albumin, then fixed in $2.5 \%$ glutaraldehyde in CSK buffer, and postfixed in $1 \% \quad \mathrm{OsO}_{4}$ in $0.1 \mathrm{M}$ sodium cacodylate, dehydrated in ethanol, dried through $\mathrm{CO}_{2}$ critical point, sample was then processed for whole mount TEM observation, examined with a JEM-100CX transmission electron microscope. Control studies were performed by substituting PBS or non-immunized serum for antibody.

\section{RESULTS AND DISCUSSION}

\section{1. $10 \mathrm{~nm}$ filaments and immunogold labelling}

Protoplasts pellet was suspended in an equal volume of washing buffer and one drop of this suspension was placed onto each poly-L-lysine-coated grid. We used Penman's method for cell fractionation with some modifications. After plant cells were treated with CSK-Triton and RSB-Magik solution, a delicate IF-like network could be shown in cytoplasm when viewed by TEM. Cytoskeletal network was mainly composed of $10 \mathrm{~nm}$ filaments consistent with IFs of animal cells. They formed side to side, but no side to end anastomoses (Fig. 1). The diameters of the single fila-

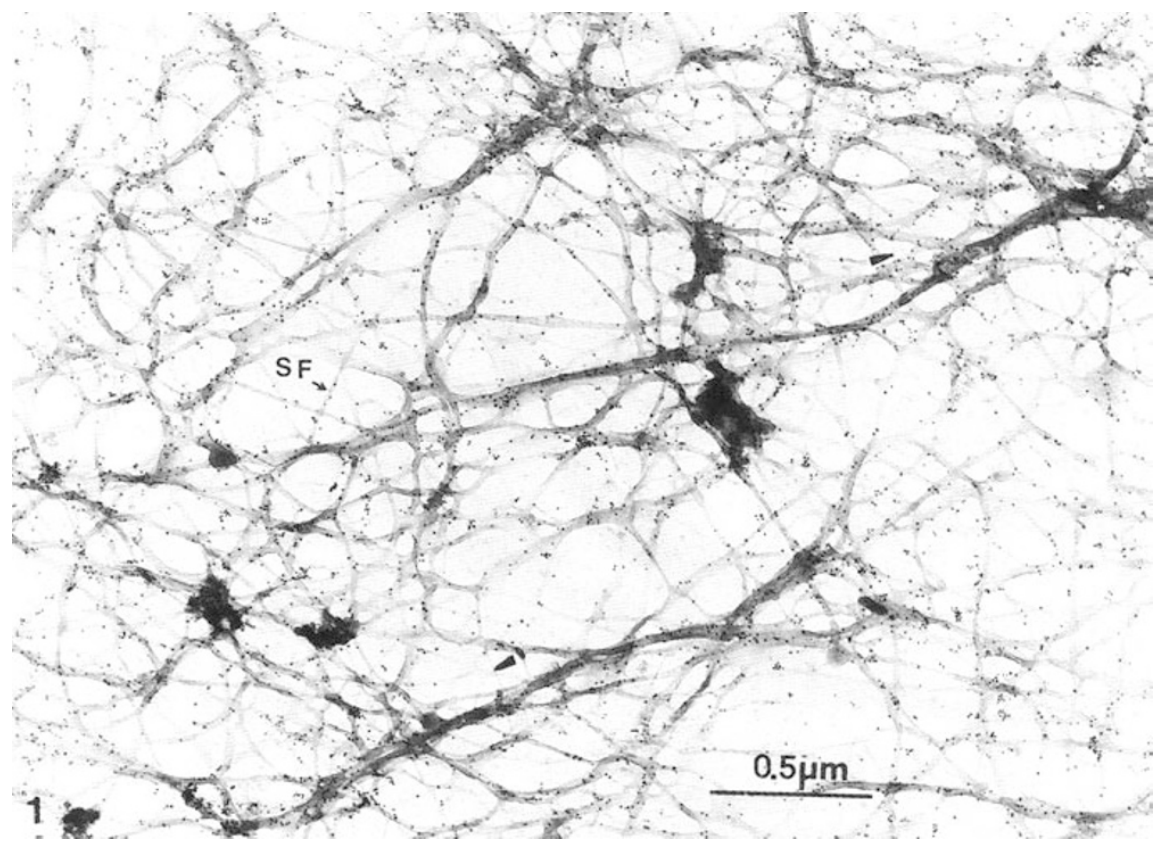

Fig. 1 Electron micrograph of extracted maize prtoplasts.

Keratin IF-like system is shown. SF: single filament, diameters about $10 \mathrm{~nm}$. Many gold particles $(5 \mathrm{~nm})$ are bound to the filaments. Some individual filaments join together to form bundles by side to side anastomosis. Note that there are thiner filaments of diameter about $3 \mathrm{~nm}$ (arrows). 
Keratin intermediate filament-like system in maize protoplaste

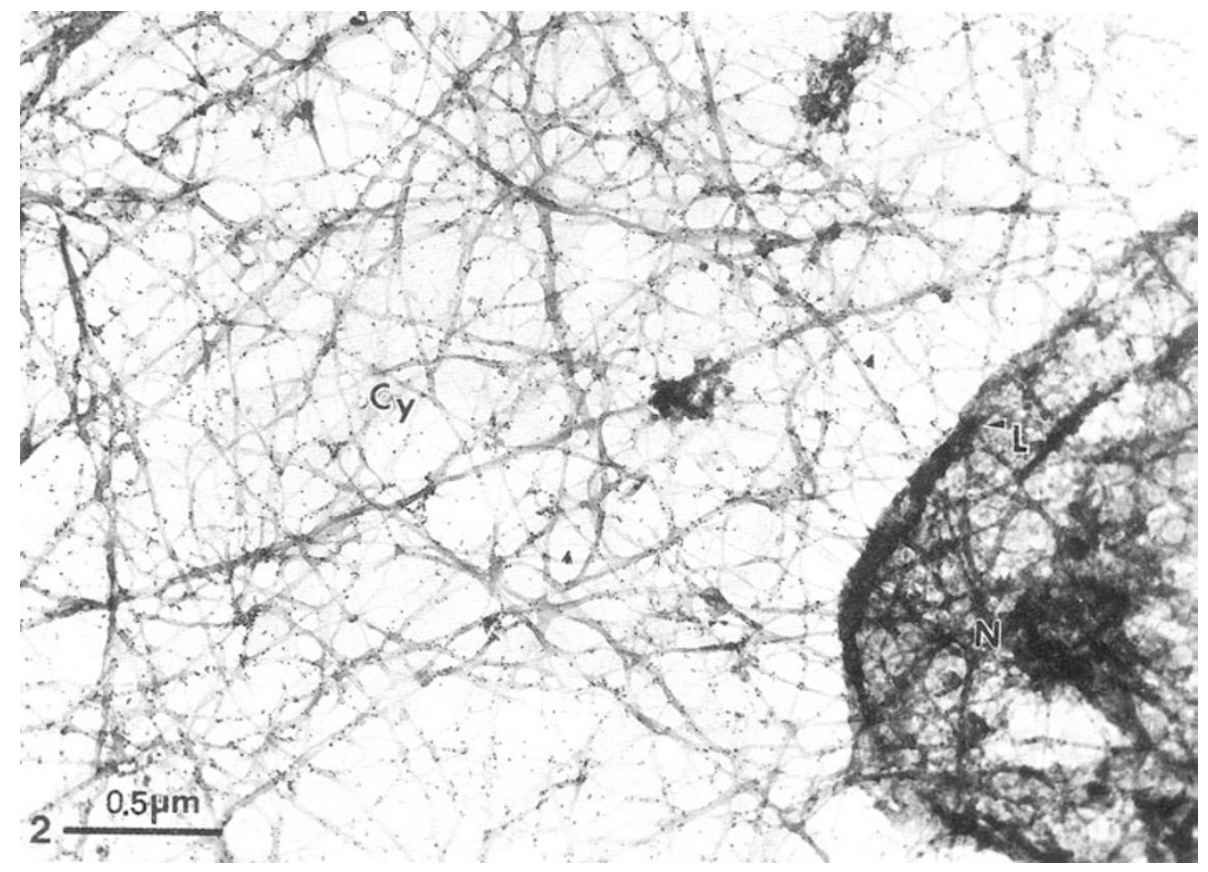

Fig. 2 IF-like filaments-Lamina-Nuclear matrix system in maize protoplasts.

$\mathrm{N}$ :Nuclears, L:Lamina, Cy:Cytoplasm. Note that many $3 \mathrm{~nm}$ filaments link IFs forming T-or Y-shaped branches (arrows). × 640000.,

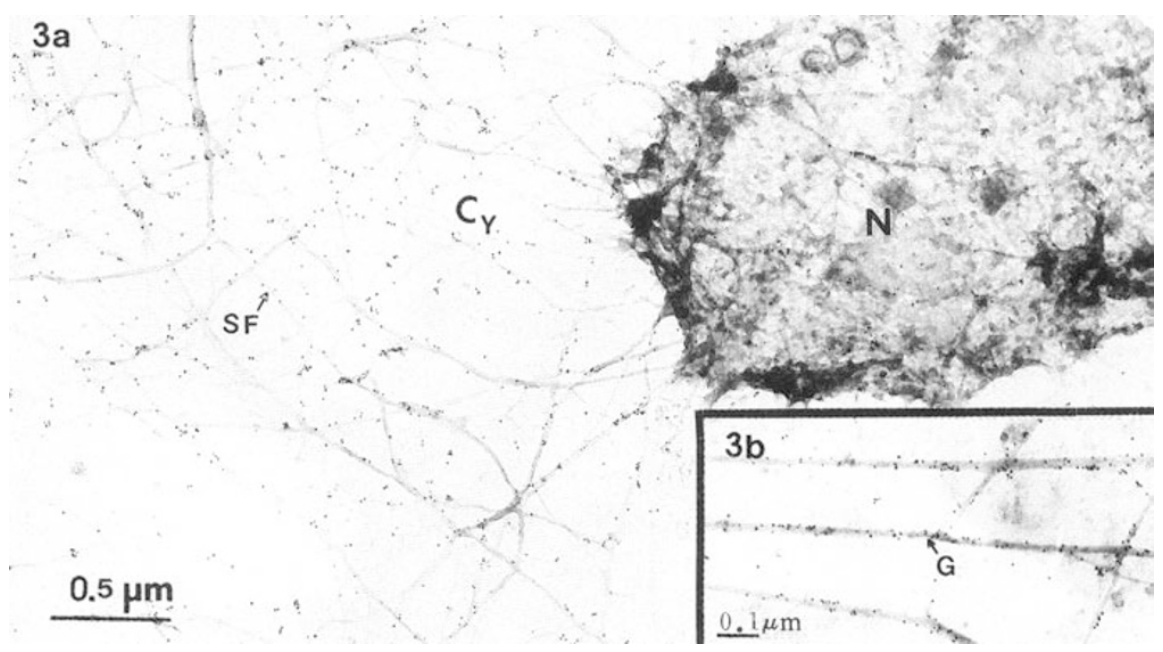

Fig. 3 Delicate keratin IF-like system was shown after immunogold staining in extracted maize protoplasts.

G:Gold particles ( $5 \mathrm{~nm}$ ), N:Nucleus, Cy: Cytoplasm, SF:Single filaments.

(a) The nucleus was spatially anchored by cytoplasmic filaments, $\times 52,000$;

(b) Higher magnification of $10 \mathrm{~nm}$ filaments, gold particles (5 $\mathrm{nm}$ )line up on the filaments. $\times 72,600$. 
ments were about $10 \mathrm{~nm}$. The individual IF often joined together to form bundles of filaments by side to side anastomoses (Figs. 1, 2). Filament ends were rarely observed except when they were broken by the bombardment of the electron beam, indicating that these IF-like filaments run for long distances through the cells. After immunogold labelling, a great number of gold particles (5-7 nm) were found to be bound to IF-like filaments (Figs, 1-3). This demonstrated that these $10 \mathrm{~nm}$ filaments were very similar to IFs in animal cells, and their main component was keratin. The immunogold staining was not evenly distributed, with more gold particles crowded together at certain place on some filaments and with only fewer scattered particles on other filaments. We suggested that cytokeratin distribution is uneven in IF-like filaments of plant cells. All these have not been reported before.

\section{IF-like filaments-lamina-nuclear matrix system in plant cells}

After further extraction by DNase I and 0.25 $M$ ammonium sulfate, chromatin was removed. An IF-like filaments-lamina-nuclear matrix system appeared. The nuclei maintained their shape and position, and were spatially anchored by cytoskeletal network. It is very interesting that nuclear matrix was also connected with lamina (Fig. 2). So in plant cells (maize protoplasts), there exists an independent IF-like filament-lamina-nuclear matrix system, which is a Triton X-100-resistant skeletal framework, and also a nuclease and salt-resistant NM-IF scaffold. By using immunogold labelling, many gold particles could be found not only on filaments but also on the surface of plant cell nuclei. No specific binding of gold particles to filaments could be found in the control test. All these $10 \mathrm{~nm}$ filaments, lamina and nuclear matrix connected together to form a complete network spreading over cytoplasm and nuclei in plant cells, just like in animal cells.

\section{3. $3 \mathrm{~nm}$ filaments, the fourth cytoskeletal element}

Thinner filaments of about $3 \mathrm{~nm}$ diameter were observed. These thin filaments formed a bridge between $10 \mathrm{~nm}$ filaments, making end to side attachments. They also formed T- or Y-shaped branches (Fig. 1,2). Schliwa et al. demonstrated that $3 \mathrm{~nm}$ filaments linked together three major cytoskeletal filaments, i.e. microtubules, IFs and microfilaments[14,15,16]. They found that the highest association was with IFs. Protein composition of the $3 \mathrm{~nm}$ filaments has not been characterized. Katsuma et al. suggested that $3 \mathrm{~nm}$ filaments is the fourth cytoskeleton element[ 17 ]. It seems that this filament playsan important role in major elements of cytoskeleton although the nature of this fourth cytoskeletal element is still obscure. The demonstration of this $3 \mathrm{~nm}$ filament in plant cells may will be beneficial for more in depth studies of function and morphlogic characteristics of this element.

\section{REFERENCES:}

[ 1 ] Ishikawa H, Bischoff R, Holzer H. Mitosis and intermediate-size filaments in develo- 
ping skeletal muscle. J Cell Biol 1968; 38:538-51.

[2] Ishikawa H, Bischoff R, Holzer H. Formation of arrowhead complexes with heavy meromyosin in a variety of cell types. J Cell Biol 1969; 43:312-28.

[3] Blose SH, Shelanski LM, Chacko C. Localization of bovine brain filament antibody on intermediate filaments in guinea pig vascular endothelial ceils and chick cardiac muscle cells. Proc Natl Acad Sci USA 1977;74:662-5.

[4] Woodcock CLF. Nucleus-associated intermediate filaments from chicken erythrocytes. ,J Cell Biol 1980;85:881-9.

[5] Fey EG, Wan KM, Penman S. Epithelial cytoskeletal framework and nuclear matrixintermediate filament scaffold three-dimensional organization and protein composition. J Cell Biol 1984:98: 1973-84.

[6] Capco DG, Wan KM, Penman S. The nuclear matrix: Three dimensional architecture and protein composition. Cell 1982; 29:847-58.

[7] Zhai ZH, Krochmalnic G, Penman S. The association of vaccinia virus with intermediate filament. Science Sinica (B) 1988; 10:1076-80.

[8] Zhai ZH, Krochmalnic G, Nickerson JA, Penman S. Alterations in nuclear matrix structure after adenovii-us infection. J Virol 1987; 61:1007-18

[9] Zhai ZH, Wang X, Qian XY. Nuclear matrix-intermediate filament system and its alteration in adenovirus infected HeLa cell. Cell Biol Int Rep 1988; 12:99-108.

[10] Dawson P J, Hulme JS, Lloyd CW. Monoclonal antibody to intermediate filament antigen cross-reacts with higher plant cells. JCell Biol 1985; 100: 1973-8.

[11] Miller CJ et al. Plant cytoskeletons contain intermediate filament, related proteins. Biochem Soc Trans 1985; 13:960-1

[12] Edwards GE, Lilley RM, Craig S, Hatch MD. Isolation of intact and functional chloroplasts from mesophyll and bundle sheath protoplasts of the $\mathrm{C}_{4}$ plant Panicum miliaceum. Plant Physiol 1979; 63:821-7.

[13] Van Der Valk, Rennie PJ. Connolly JA, Fowke LC. Distribution of cortical microtubules in tobacco protoplasts: An immunofluorescence microscopic and Ultrastructural Plan study. Protoplasma 1980; 105:27-43.

[14] Schliwa M, Blerkom J. Structural interaction of cytoskeletal components. J Cell Biol 1981; 90:222-35.

[15] Schliwa M. Action of cytochalasin D on cytoskeletal networks. J Cell Biol 1982; 92: 79-9 1.

[16] Schliwa M, Pryzwansky KB, Blerkom J. Implications of cytoskeletal interactions for cellular architecture and behaviour. Phil Trans R Soc Lond B229 1982; 199-205.

[17] Katsuma Y. Swierenga SHH, Marceau N, French SW. Connections of intermediate filaments with the nuclear lamina and the cell periphery. Biol Cell 1987; 59:193-204. 